\title{
STUDENT MOVEMENT IN PUBLIC POLICY FORMULATION
}

\author{
Aziz Nana Abdul \\ Faculty of Administrative Sciences, University of Brawijaya, Malang, Indonesia \\ E-mail: nanaabdulaziz13@gmail.com
}

\begin{abstract}
Dynamic situations and conditions are one of the reasons behind the re-enthusiasm of student movements that were previously in a state of deterioration due to regime repression. First, the excesses of the political education character run by the new order, a closed and less dialogical political education. This kind of education character is a fertile ground for the growing discontent and political disappointment among young people and students. Young people and students who care about marginalized communities due to development politics continue to conduct intensive and intensive studies, take to the streets, and shout out the need for democracy to grow. Third, the student's anxiety sees the will of political stabilization and a strong new order economy. In the midst of situations like this is to think and be critical of it. The emergence of KAMMI, accompanied also by the existence of the College Student Senate or Student Executive Board amid rampant student demonstrations in various campuses in Indonesia, giving new nuance, increasingly encourage the media skills in making ideas as a big agenda a nation that attracts students. The time passes in the dynamics of the changing times, when the tides of tidal movements, the big question is the role that the student movement must play in the era of open democracy. What kind of struggle tactics should be used in the role of public policy formulation? This paper explains the role of the student movement in the formulation of public policy, with a qualitative descriptive approach; aims to provide a detailed, historical explanation of a particular phenomenon.
\end{abstract}

\section{KEY WORDS}

Student movement, public policy, public policy formulation.

Students are undoubtedly well-known for being dominant actors who hold strong role and influence in every scene of the history of Indonesia's reformation. The nascence of 1908 , 1928, and 1945 generations which was later followed by the raise of the 166, 1974 and 1978 until the 1998 generations are the historical evidence of the intelectual youth movement in Indonesia (Atip Tirtana dalam Naipospos \& Fadhly, 1999).

In the end of 1998, a prolonged monetary crisis struck Indonesia, causing Rupiah to drop dramatically at $\mathrm{Rp} 16.000$ against dollar due to declining amount of of market stock for production activities were forced to stop and distribution channels were destructed by the May 1998 riots of Indonesia Unit Khusus Museum Bank Indonesia: Sejarah Bank Indonesia). This crisis affected other aspects, even the unrest became the worst economic and political crisis. The society, especially the poor people were the most affected ones by this crisis. According to Kwik Kian Gie (dalam Rakhmat \& Najib, 2001), the major cause of this crisis was related to foreign investment issues. Whilst, Mar'ie Muhammad (dalam Rakhmat \& Najib, 2001) in a speech delivered in Asia Society Conference in New York December 1997, stated that the crisis was caused by sudden lack of confidence by foreign investors, inconsistency of national policies, lack of consistency in economic reformation, lack of transparency, vulnerable financial sector, huge foreign debts, weak economic fundamentals, mistrusts, globalization effects, unbalanced market dominance, and investors' anxiety.

In the midst of this unstable nation condition, students took the lead to show their strategic role in the nation. Through campus organizations such as the Senat Mahasiswa Perguruan Tinggi (SMPT) or the Senate of University Students which presently is called Badan Eksekutif Mahasiswa (BEM) or the Executive Director of University Students, held massive protests to take down power of the new order government. In early 1998, students 
were re-triggered to held social protests prior to their disagreements toward the policies government.

Students in 1998 appeared as the most responsive party to react upon government policies. Students from various organizations joined the movement including the moslem students of Indonesia, nationalist students, and other organizations that went against the government. In the movement, moslem students took the lead. They attempted at giving positive contributions in the forms of alternative solutions to solve various problems as an expression of their ideology responsibility. They stuck to the principle taught by the Prophet Muhammad SAW that "the best people are those who benefit other people" (Rakhmat \& Najib, 2001).

Seen from the perspective of Indonesian History, students' participation in social problems is not an uncommon thing. It was stated by Radjab (in Rakhmat \& Najib, 2001), students were regarded as the only effective opposition. However, through Normalisasi Kehidupan Kampus (NKK) or the act of campus normalization, the new order government managed to hegemonized students' movement. Despite of the statement of Eef Saefulloh Fatah (in Rakhmat \& Najib, 2001), that the 90s was the renaissance era for students of Indonesia, there were conditions that caused revival of students' enthusiasm which had been in a dead faint due to the regime's pressure. First, the excess of politic education implemented by the new order which spoon-fed the students with undemocratic and one-way teaching. This character in education sector has triggered students' dissatisfaction and disappointment. Second, the excess of the political development done by the new order. The youths and students had a huge concern about the condition of the marginalized society caused by the political development, leading them to administer active and intensive protests on the street, demanding better democracy. Third, students were anxious about the unstable politics and economy condition in the new order governance. Students had the urgency to think and act critically toward those false policies.

Those three factors led to the raise of various intellectual groups and organization that gather students' political insights, and other NGOs, especially in secular campuses such as UI, ITB, IPB, UGM and UB to revive the ideology spirit of Islam. Students' enthusiasm to learn and carry out Islamic teaching had been able to change the term BUTA PESTA (Buku, Cinta, dan Pesta) or Books, Love and Party, into BUNGA DAKWAH (Buku, Ngaji dan Dakwah) or Book, Learning Qoran, and Teaching Islam (Rakhmat \& Najib, 2001).

A number of Islamic organizations were born in both state-owned universities and private universities. The awareness of the importance to apply religious values in personal life, families, society and in the nation grew rapidly. Students were certain to apply religious solutions in solving various problems that occurred in the era. Students also built Forum Silaturahmi Lembaga Dakwah Kampus (FSLDK) or a forum to facilitate discussions on Islam that adjoined some organizations from various universities. In the forum, moslem students from various universities gathered and held discussions about Islamic da'wah (Rakhmat \& Najib, 2001).

The $10^{\text {th }}$ forum was held in Muhammadiyah University Malang to discuss about prolonged crisis in Indonesia. Moslem student activists who attended the forum agreed to take part in finding solutions of the problems. They reached this agreement as they wanted to hold their ideology as moslems as well as to take the responsibility for the history of Indonesia. Actually, the idea to build this organization was a spontaneous idea that appeared in the $10^{\text {th }}$ forum in Malang held in Friday to Monday, (25 - 19 March, 1998). The forum was attended by 69 Islamic Da'wah Campus Organization with 200 members. The members were students from campuses in Java, Sumatera and Borneo. Moreover, in the forum, they also agreed to follow up ideas that had been collected to be discussed outside the forum (Rakhmat \& Najib, 2001).

Students believed that there were at least two reasons why real actions should be administered to generate the potentials of moslem students, especially those who had been registered as the members of LDK (Lembaga Dakwah Kampus) or Campus Da'wah Organization. First, the empathy that they felt prior to the national crisis that struck Indonesia, and they were also triggered by their moral responsibility to find solutions for the agony of 
Indonesian people that motivated them to put their good intentions into real active actions to bring the nation to better future. Second, agreement reached in the $10^{\text {th }}$ National FSLDK to held coordination and consolidation inter campuses, particularly the LDK to build a peace power that gives moral pressure to the government. In the forum, it was also agreed to create certain organization that coordinated and united various $L D K$ to get themselves more focused on their political agenda (Rakhmat \& Najib, 2001).

In Monday, March $29^{\text {th }}, 1998$ which was also the $1^{\text {st }}$ day of Djulhijjah $1418 \mathrm{Hijri}, K A M M I$ (Kesatuan Aksi Mahasiswa Moslem Indonesia) was established as stated in DEKLARASI MALANG or the Declaration of Malang. KAMMI became an organization that consistently made efforts to bring total reformation for the nation (Rakhmat \& Najib, 2001).

The establishment of KAMMI was also followed by more active attitude of student senate or the executive board of students in joining the protests in several campuses in Indonesia, giving fresh atmosphere that reformatted the ideas into a big plan for the betterment of the nation. Time kept running within the dynamicity of the era of change, and when students' movements were fluctuate, questions remained unanswered; what role the students should play in the era of open democracy and what strategies should be used to take part in the public policy making.

\section{LITERATURE REVIEW}

\section{Social Movement:}

The Concepts and Theories of the New Social Movements. The new social movement is the latest theoretical approach that explains the changes of social movement characters (Sukmana, 2016). The theory of the new social movement can be identified through general approaches. First, the new social movement highlights the symbolic actions done by certain society or culture as a collective actions as well as instrumental actions in certain political environment or certain nation (Cohen in Sukmana, 2016). Second, the new social movement emphasizes on the importance of the process that promotes autonomy and selfdetermination, instead of focusing on the strategies used to optimize ones' influence and power (Habemas in Sukmana, 2016). Third, the concept also focuses on the role of post materialist values in various collective contemporary actions to prevent conflicts in certain material (Inglehar in Sukmana, 2016).

The Characteristics of the New Social Movement. Pichardo (in Sukmana, 2016) stated that the paradigm of the new social movement fundamentally has some distinct characters from the old one. There are four characters of the new social movement, which are 1).ideology and goals, 2).tactics, 3).structure, 4).participants of contemporary movements

The Typology of the New Social Movement. Buechler stated (in Sukmana, 2016) that generally, theories of new social movement are classified into two types; political version and cultural version. The difference between those two types is not exclusive, instead it rather deals with different positions and different dimensions.

Public Policy:

Characters and Substances of Public Policy. Regarding to the terminology, the term policy does not only refer to something textual, instead it is rather contextual for it changes over time. Thus, the meaning of this term is not homogeneous since it adjusts to the dynamicity of socio-economic and political actions that occur in a society, and it is also influenced by the perceptions of the society (Wahab, 2011).

There are currently ten insights of the term policy as mentioned by Brian W. Hogwood and Lewis A. Gunn (in Wahab, 2011) which includes: 1) Policy is a brand or label given for programs run by government, 2). Policy is a statement about general objectives or certain targets, 3). Policy is special opinions, 4) Policy is government's decisions, 5) Policy is a form of formal legalization, 6). Policy is a set of programs, 7). Policy is an output, 8). Policy is a final result, 9). Policy is a theory or model, 10). Policy is a process.

Regarding to those insights and considering the context referred by students about public policy making, policy is seen as a process (number 10). It is also stated by (Wahab, 2010) that if policy is seen as a process, which refers to political process, then it should be 
also perceived as a cycle. The cycle of this issue is in the form of convey bell, then public policy making starts from the occurrence of certain issues in the society which demand the government to find alternative solutions to solve them through adoption of certain policies to be later implemented by certain institutions or personnel. The implementation is then evaluated, modified and eventually it is terminated when the targets are achieved. Either or no the success of the policy really happens or it is merely something perceived does not appear as the matter.

Regarding to those insights, it can be put into a conclusion that public policy is a government's instruments that involve other parties and organizations both private organization and NGOs. Policy actually means a choice of action that directly control the management and distribution of natural, financial and human resources to benefit the public or the society. Policy is made out of a synergy, compromise, and competition of various ideas, theories, ideologies, and interests within certain political system applied in a nation.

Steps of Public Policy Making. Public policy making is a complex process involving a number of steps and variables to be reviewed (Winarno, 2016). Some experts classify public policy making into several phases. 1) Public policy formulation, 2). Policy formulation, 3). Policy adoption, 4). Policy implementation, 5). Policy evaluation. Yehezkel Dror (in Wahab, 2011) also explained in details that the public policy making refers to a complex and dynamic process consisting of various elements, each of which holds different functions in every policy making. Public policy making determines the general guidelines to be applied in the future, especially by government's departments or organizations. Regarding to the explanation about public policy making proposed by Dror, it can be understood that there are 12 characteristics of public policy making: 1). Very complex, 2) The process is dynamic, $3)$. There are various elements, 4). Each sub-structure holds a different function, 5). It decisive, 6). It provides general guidelines, 7). It is used to take actions, 8) future-oriented, 9). Implemented by the government, , 10). Meant to achieve certain target, 11). Reflection of the public interests, 12). Done in the most effective and efficient ways.

Designing a Public Policy. The design of public policy is the core of public policy itself for it is where the limitations of the policy are set. Thus, it is crucial to understand the characteristics of certain public policy. Public policy also does some interventions to the public by improving the quality of life of the society. Thus, the core of public policy is the interventions it creates. Since the main target is to give interventions, implementation of certain public policy should focus on the actions that are feasible to be done in areas that can be intervened (Nugroho, 2008).

Models of Public Policy Making. Basically, (Winardno, 2016) mentioned that at least six model apply in the public policy making, they are 1). David Easton's Model, 2), The Rational Comprehensive Model, 3). Satisfaction-based Model, 4). The Incremental Model, 5). The Mixed-Scanning Model, and 6). The Optimal Qualitative Model. The context of this study matched the model system since students' movements are parts of the civil society that trigger policy issues.

\section{METHODS OF RESEARCH}

This paper explains the issues through a qualitative approach. Descriptive research gives detailed description of a phenomenon. The use of qualitative approach has been considered appropriate with the characteristics of the objects and the social phenomena that were being observed. As mentioned by (Sugiyono, 2007) qualitative method is often referred as a naturalistic approach since the observations should be done in natural settings.

\section{RESULTS AND DISCUSSION}

The Development of Students' Movement. In the history of Indonesia, students have been known to give huge contribution as the element that promotes historical changes. Students possess two resources that fuel up their subjective awareness which later become the power to conduct political activities. First, intelligence which is a combination between 
systematic knowledge and scientific behaviors to understand the social condition. Second, students possess a privilege in the form of special social identity they got from the previous students. For instance, in Malang, students' movements still exists. Even after the reformation, students kept working on the improvement of their organizational structure and strengthening their position as the social organizations. Every university facilitates students with organizations to join. The number of organization branches kept growing in public and private universities indicating that the network got broader. Table 1 shows the timeline of the development of students' movement over periods.

Table 1 - The Development of Student Movement across Periods

\begin{tabular}{|c|c|c|}
\hline Period & Movement Pattern & $\begin{array}{l}\text { Issues and Demands } \\
\end{array}$ \\
\hline $\begin{array}{l}1967- \\
1979\end{array}$ & $\begin{array}{l}\text { Relatively consolidated after the } \\
\text { establishment of } D E M A \text { (Dewan Mahasiswa) }\end{array}$ & $\begin{array}{l}\text { The conditions were political, easily provoked by } \\
\text { political issues that had not yet involved the role of } \\
\text { students. }\end{array}$ \\
\hline $\begin{array}{l}1980- \\
1989\end{array}$ & $\begin{array}{l}\text { The focus was on the NGOs. Academic } \\
\text { forums made student movement scattered. }\end{array}$ & $\begin{array}{l}\text { Some NGOs demanded some issues to be taken care } \\
\text { such as issues faced by farmers about land ownership. }\end{array}$ \\
\hline $\begin{array}{l}1990- \\
1999\end{array}$ & Apart from other social actions & $\begin{array}{l}\text { Strongly political and elite, supportive for national } \\
\text { leaders, law enactment, abolition of double function of } \\
\text { the military, civic supremacy, and improvement of } \\
\text { national economy. }\end{array}$ \\
\hline $\begin{array}{l}2000- \\
2001 \\
\end{array}$ & $\begin{array}{l}\text { Student movements were polarized into two } \\
\text { poles of power. }\end{array}$ & $\begin{array}{l}\text { Criticisms upon neoliberalism vs political demand } \\
\text { (Taking down the power of Gus Dur and Megawati) }\end{array}$ \\
\hline $\begin{array}{l}2002- \\
2005\end{array}$ & Started to strengthen the identity as NGO, & $\begin{array}{l}\text { In cities such as Yogya, Malang and Bandung, students } \\
\text { expressed their ideas and interests such as the } \\
\text { demand for higher education subsidiary. In the other } \\
\text { side, some other still focused on political issues. }\end{array}$ \\
\hline $\begin{array}{l}2006- \\
2010\end{array}$ & Permanent Opposition Movements & TUGU (Tujuh Gugatan Rakyat) or the Seven Demands \\
\hline $\begin{array}{l}2010- \\
2017\end{array}$ & $\begin{array}{l}\text { The millennial era, organizations were } \\
\text { polarized, infiltrated by political interests, and } \\
\text { social medias were started to be used as } \\
\text { communication channels. }\end{array}$ & Nationalism, Stabilization of National Politics \\
\hline
\end{tabular}

Source: (M Dwi, 2005), analyzed by the author.

\section{The Strategies of Student Movements}

The student movement organizations were NGOs which had no affiliation with any political competition in the election, thus students could run their movement through parliamentary channels or more well-known as extra parliamentary, in which students acted as the opposition. This path was taken due to the dominance of the nation was too strong in controlling any public policies or any public interests. Extra parliamentary movement had been constitutionally accepted as mentioned in the verse 28 of UUD'45, in which it is stated that people have the freedom to create organizations, express their ideas and opinion orally or written, guaranteed by the Act Number 9 of 1998 about the freedom of speech. Extra parliamentary actions were also done by conducting public hearing, protests, rallies, petitions, and lobbying. Those actions were legal as explained in the Chapter I of General Guidelines of the Act Number 9 of 1998 article 1 verse 3, "Unjuk rasa atau demonstrasi adalah kegiatan yang dilakukan oleh seseorang atau lebih untuk mengeluarkan pikiran dengan lisan, tulisan dan sebagainya secara demonstratisf di muka umum". The freedom of speech is also re-explained in article 2 verse 1 "Setiap warga negara secara perorangan atau kelompok, bebas menyampaikan pendapat sebagai perwujudan hak dan tanggung jawab berdemokrasi dalam kehidupan bermasyarakat, berbangsa dan bernegara".

Other extra parliamentary movements were consolidating with other organizations to raise awareness upon certain issues and ensuring the people about the coalition. Coalition with other organizations was aimed at doubling up the power to give the government pressure and to expand their influence among the society. Besides alliances with other Organisasi Kepemudaan (OKP) or the Youth Organizations, they also tried to raise the awareness upon the society upon certain issues and shaped people's opinion by utilizing the power of mass media. In some issues, students shared similar thoughts. There were issues 
that made the bound stronger in the alliances such as issues on education, leadership and social issues.

Mass media was intensively utilized to give a spotlight to the government's performance. Students believed that government had a central and significant role to bring changes for the nation. In addition, within a paternalistic social structure like in Indonesia, leaders hold strong influence and power. The condition of the society is strongly influenced by how the government takes care of the society. This condition has led to the demand for reliable government with strong will to develop and motivate the society to achieve the nation's ideals.

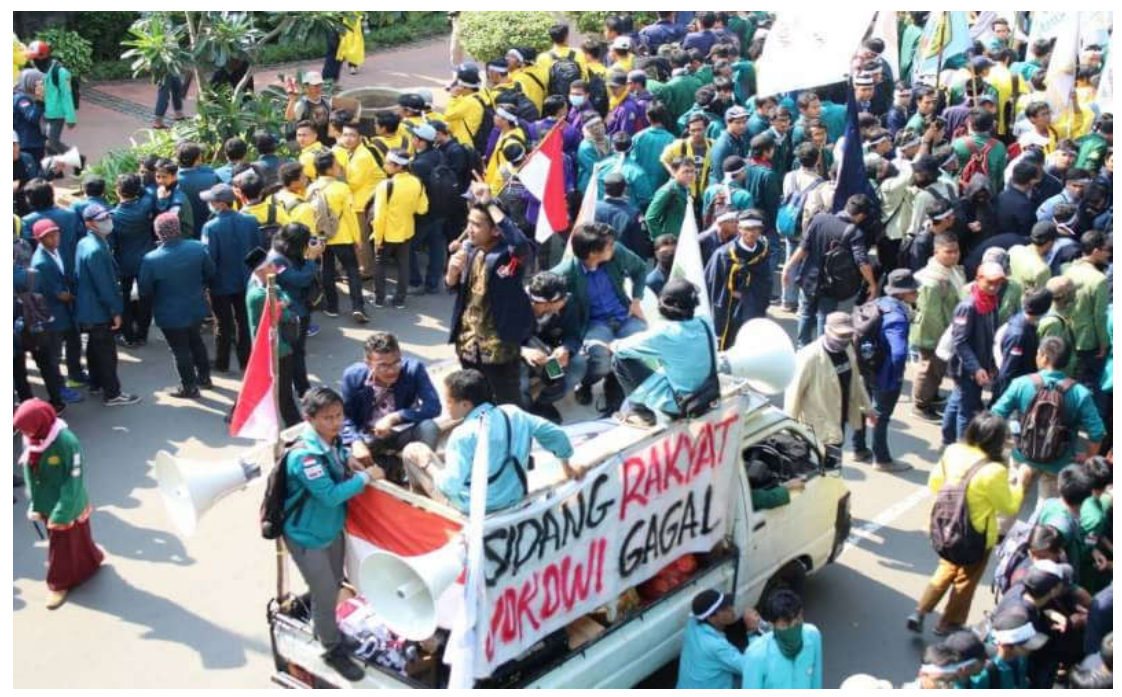

Image 1 - Students' Protest against the Government

Other strategies were also implemented to raise people's awareness upon the political issues by utilizing the printed mass media such as releasing their own magazine to spread their views for the leaders and the society. Media were also used to control the society and to evaluate the performance of the government in the local area scope. Education on politics was also provided for the leaders of students group by conducting contemporary discussions about the latest issues.

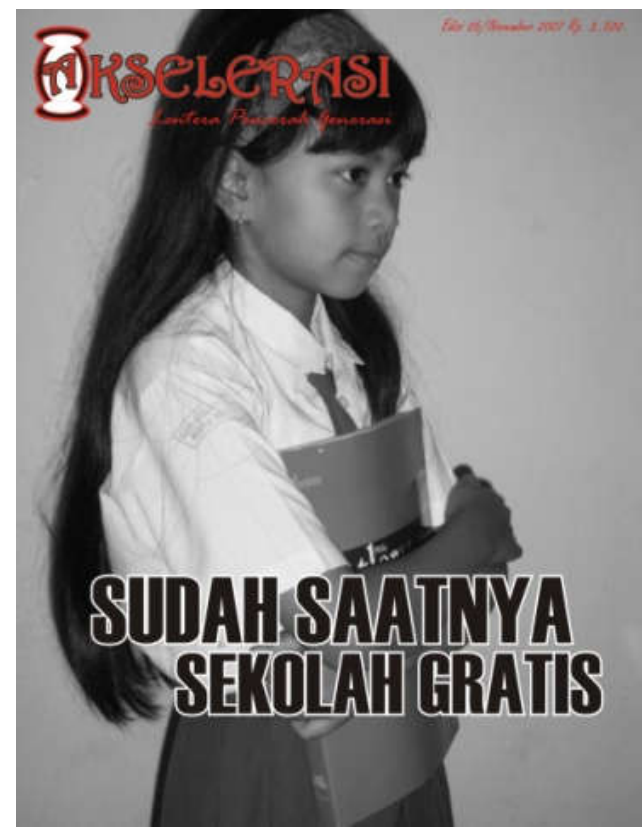

Image 2 - Cover of a Magazine as the Mean of Promoting Affordable Education 
Alliances as a Chosen Strategy. During the attempts to change and take apart in the public policy making, students were required to obtain strong bargaining position in front of the policy makers. Besides the need to have good understanding on politics, supports from other organizations and from the society were highly needed to lift up the bargaining position.

The appearance of alliances indicated that there were various strategic issues that should have been brought up through student movements. For instance, the demand upon good and affordable education had successfully strengthened the bond among NGOs. Besides, alliances got stronger for there was one target to be achieved together; wellcivilized society.

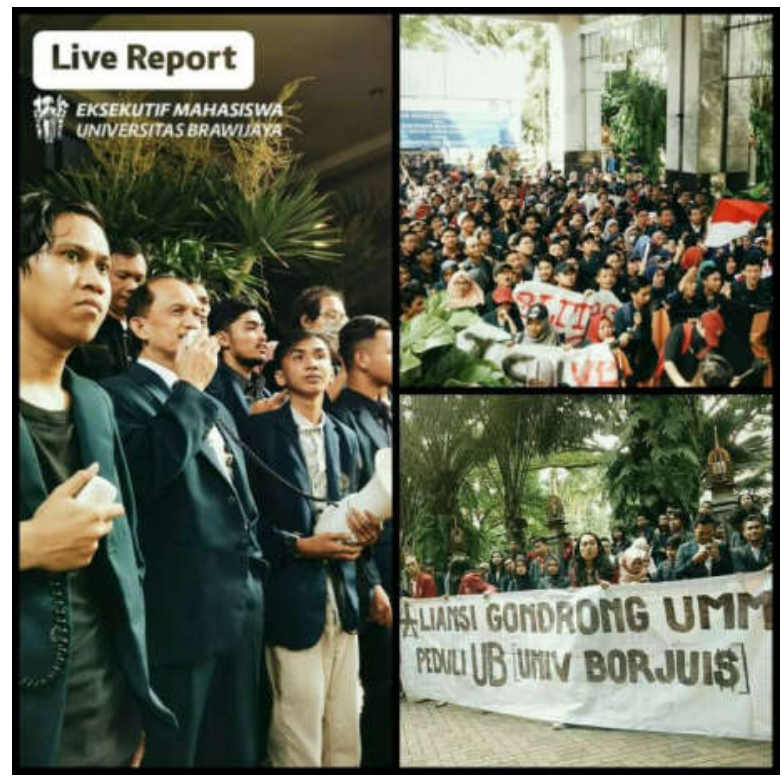

Image 3 - Student Movements Alliances as a Bargaining Position

Regarding to the fact about alliances of student movement, it is inappropriate to believe that student movement after the reformation could not unite. It is also inappropriate to say that the polarized movements were caused by different ideologies of the students since they actually alienated for they shared a similar view. The polarized movements were rather caused by different preferences of methods used in the movement. The polarization should also be seen as a certainty or a logical consequence of different views in interpreting the situations of the nation. Lack of communication among the students also resulted to various interpretation of the situations which also appeared as obstacles of the movements.

The Role of Student Movements in the Process of Public Policy Making. Before conducting deeper analysis on the role of student movement in public policy making, it is important to review and understand the term public policy itself.

Public policy refers to a set of determined actions either or not it is implemented by the government in regard to society-oriented targets. In short, public policy is a political decision made by stakeholders. Regarding to this definition, it can be understood that each public policy is an attempt made by stakeholders as the representation of the society to consolidate various interests to be directed at achieving certain objective, and every decision made prior to the policy is regarded as a legal political decision (Islamy, 2004).

In a more practical context, policy is a set of decisions or action preferences to manage and distribute natural, financial, and human resources to fulfil the need of the public or the society. A policy is made out of synergies, compromises even competitions among various ideas, theories, ideologies and other interests that represent certain political system applied in a nation. Thus, it is obvious that stakeholders hold the key role in a public policy making and the public policy implementation. Their role gets stronger as they are the ones who will eventually obtain the results of the policy. Therefore, stakeholders' authorities in the process 
of public policy making should be carefully pre-determined to guarantee the effectiveness of the process and the implementation of certain policy.

Theoretically, in a local scope, The House of Regional Representatives is the policy makers who represent the aspiration of the society, and the House of Representatives also holds the responsibility to manage social conflicts as well as running their integrative functions in the society. As stated in the ideals of the Indonesian reformation, the roles and the functions of The House of Representatives are more directed at being the government's vital organs in the regional area who speak up for the society to support the reformations of politics and economy. Those missions are meant to get the policy makers closer to the people who will be directly influenced by the implementation of certain policies. Technically, The House of Regional Representatives also creates rules and regulations in regional areas. However, generally, this function is the way to express society's ideas. Thus, the focus should not be put on the finished regulation product, but the main concern is how the policy makers weigh the aspirations from the society into the policy. Within the context of democratic system that regards the role of civil society, society should be seen as interest groups who possess the potentials in the politics and certain function in government's institutions. Unfortunately, the society who should be regarded as the stakeholders, is rarely involved in policy making process. The idea to give place for non-government parties to be actively involved in the policy making process and to be given authorities to monitor and criticize government's performance has not yet been put into real action. In fact, synchronization between the House of Regional Representatives and the society is merely done as a complementary legitimation.

Considering the conditions of the governance run by the government, students have set up their own strategies to be able to actively participate in every process of public policy making. As mentioned by Nigro and Nigro (1980), a number of aspects affect the process of public policy making, which are:

- Outer pressures; even though a public policy has been created out of rational logics, pressures from certain parties might influence the process of public policy making.

- The power of conservatism; old habits implemented in an organization will be also practiced by the next generations, moreover when the habits are considered good.

- Personality influences; personalities of public policy makers also influence the policy making process.

- Influences of other groups; the social environment around the policy makers also influences the process.

- Past experiences; past experiences also have certain influence in policy making process.

From the explanation, it is certain that as one of political power, students still have the opportunities to be actively involved in the policy making process. As a mass organization, students are allowed to give political pressures toward any inappropriate policies taken by the government through acceptable ways that do not go against the law and regulations in Indonesia. Pressures from the students should be taken into account in creating certain public policies to give the most benefits for the society. Unfortunately, stakeholders often neglected these pressures from students, resulted to the failure of the pressures in interfering inappropriate public policies. The right to conduct extra-parliamentary actions does not permit students to determine any public policies, instead they are only allowed to interfere the process.

\section{CONCLUSION}

Society possesses the rights to be actively involved in any political processes, especially in policy making process, which policy gives direct effects to them. Therefore, as an independent party, students have to take part in the process of public policy making. Unless, the society and students will be resistant to accept the policy. Mass actions and alliances are alternative strategies to get higher bargaining power in front of policy makers. There is an indication that extra-parliamentary right weakens students' bargaining power. 
Thus, they are only able to influence and interfere the policy making process but they are not allowed to change the policy.

After the reformation, the structure of student organizations gets better. This can be seen from the growing number of student movement organizations in universities all over Indonesia, and they even start to strengthen their network across provinces in Indonesia. Movement against tyranny government requires massive and systematic actions. Student organization should recruit more people to obtain higher bargaining power. In addition, selforiented actions or any actions that benefit only few parties are the main obstacles that should be overcome by public policy makers.

\section{REFERENCES}

1. Islamy, I. (2004). Prinsip Prinsip Perumusan Kebijakan Negara. Jakarta: Bumi Aksara.

2. M Dwi, N. (2005). Dinamika Gerakan Mahasiswa Pasca Reformasi. Malang: Universitas Brawijaya.

3. Naipospos, B. T., \& Fadhly, F. Z. (1999). Mahasiswa menggugat: Potret Gerakan Mahasiswa Indonesia 1998. Bandung: Pustaka Hidayah. Retrieved from http://books.google.com/books?id=jEpxAAAAMAAJ

4. Nugroho, R. (2008). Public Policy. Jakarta: PT.Elex Media Komputindo.

5. Rakhmat, A., \& Najib, M. (2001). Gerakan Perlawanan dari Masjid Kampus. Jakarta: Purimedia.

6. Sugiyono. (2007). Metode Penelitian Kuantitatif Kualitatif Dan R\& D (3rd Ed). Bandung: Penerbit Alfabeta.

7. Sukmana, O. (2016). Konsep dan Teori Gerakan Sosial. Malang: Intrans Publishing.

8. Wahab, S. A. (2011). Pengantar Analisis Kebijakan Publik. Malang: UMM Press.

9. Winarno, B. (2016). Kebijakan Publik Era Globalisasi Teori, Proses dan Studi Kasus Komparatif. Yogyakarta: CAPS (Center of Academic Publishing Srvice). 